\title{
Anticardiolipin Antibodies in Crohn's Disease Associated with Diabetes Mellitus
}

\author{
Akio Kanda, Masahiro Arakawa and Yasuhiko SASAKI
}

\begin{abstract}
We present a 58-year-old man with hyperglycemic subcoma. His blood glucose level was 1,163 $\mathrm{mg} / 100 \mathrm{ml}$ on admission and the data of the coagulate system revealed abnormalities in the prothrombin time, fibrinogen and serum fibrin degradation products. Continuous intravenous insulin infusion therapy (CIII) was performed, and a satisfactory recovery of consciousness level and blood glucose level were obtained. Further examination revealed the patient had Crohn's disease (CD) associated with IgG and IgM anticardiolipin antibodies (aCLs). The patient was treated with corticosteroid hormones and salazosulfapyridine, and the abnormalities in the coagulate system returned to the normal range and aCLs eventually disappeared. It was speculated that in such a case, anticardiolipin antibody may play a role in the pathogenesis of CD. (Internal Medicine 35: 866-870, 1996)
\end{abstract}

Key words: hyperglycemic subcoma, coagulate system, thrombosis

\section{Introduction}

While the pathogenesis of Crohn's disease $(\mathrm{CD})$ remains unknown, certain features of this disease have been suggested (1), and thromboembolic complications have reported to be frequent in CD (2-12). On the other hand, anticardiolipin antibody (aCL), which is a direct antibody against anionic phospholipids (2), was first detected in a case of systemic lupus erythematosus (SLE) with thrombosis (13); thereafter aCL was described in patients with $\mathrm{CD}(3,11)$. Here, we report a case of $\mathrm{CD}$, in which the patient's first symptom was hyperglycemic subcoma associated with aCLs, which disappeared following excellent clinical improvement by treatment with corticosteroid hormones and salazosulfapyridine.

\section{Case Report}

A 58-year-old Japanese man was admitted to our hospital with hyperglycemic subcoma on September 20, 1994. The patient's and his family's medical histories were not contributive to diabetic subcoma. From September 14, 1994, he had suffered from a high fever of $38^{\circ} \mathrm{C}$, and polyuria and polydypsia appeared day by day. The patient had no history of abdominal pain, diarrhea or bloody stools before admission. Initial examination showed blood pressure of $124 / 80 \mathrm{mmHg}$ and a regular pulse rate of $100 / \mathrm{min}$. His body temperature was $37.8^{\circ} \mathrm{C}$, and consciousness level was 10 on the Japanese coma scale (14). Lung and heart sounds were clear. Anemia and icterus were not revealed on palpebral and bulbar conjunctiva. A hard fist-sized mass was palpable in the right lower abdomen with no spontaneous pain or tenderness. The laboratory data on admission were as follows (Table 1): white blood cell count, $20,500 / \mathrm{mm}^{3}$; red blood cell count, $495 \times 10^{4} / \mathrm{mm}^{3}$; hemoglobin level, $15.2 \mathrm{~g} /$ $100 \mathrm{ml}$; platelet count, $33.0 \times 10^{4} / \mathrm{mm}^{3}$; serum sodium, 122 $\mathrm{mEq} / l ;$ serum potassium, $6.9 \mathrm{mEq} / l ;$ serum chloride, $81 \mathrm{mEq} / l$; blood glucose, $1,163 \mathrm{mg} / 100 \mathrm{ml}$; and HbA1c, 7.4\%. Urinalysis revealed glycosuria and ketonuria. C-reactive protein was 10.3 $\mathrm{mg} / 100 \mathrm{ml}$. The arterial blood gas data were $\mathrm{pH} 6.996, \mathrm{HCO}_{3}{ }^{-}$ $3.1 \mathrm{mmol} / l$, and $\mathrm{BE}-28.4 \mathrm{mmol} / \mathrm{l}$. The data of the blood coagulate system as follows: prothrombin time, $36 \%$; activated partial thromboplastin time, 40 second; fibrinogen, $558 \mathrm{mg} / 100$ $\mathrm{ml}$; and serum fibrin degradation products, $30.1 \mu \mathrm{g} / \mathrm{ml}$. Examination of eye fundus revealed no abnormalities.

Ketotic diabetic subcoma was diagnosed, and CIII treatment was started. Following the start of treatment, the patient's consciousness level and blood glucose level immediately improved, as shown in Fig. 1. A plain abdominal roentgenogram showed enlargement of the sigmoid colon (Fig. 2). A computed tomographic scan of the pelvic region showed enlargement of the colon (Fig. 3). A barium enema of the colon revealed serrated mucosa, a cobblestone appearance and a longitudinal ulcer in the sigmoid colon, and no involvement in rectum (Fig.

From the Department of Internal Medicine, Ishinomaki Red Cross Hospital, Ishinomaki

Received for publication December 8, 1995; Accepted for publication July 31, 1996

Reprint requests should be addressed to Dr. Masahiro Arakawa, the Department of Internal Medicine, Ishinomaki Red Cross Hospital, 1-7-10, Yoshino-cho, Ishinomaki, Miyagi 986 


\section{aCLs in Crohn's Disease}

Table 1. Laboratory Data on Admission

\begin{tabular}{|c|c|c|c|}
\hline \multicolumn{2}{|l|}{ Hematology } & Blood glucose & $1,163 \mathrm{mg} / 100 \mathrm{ml}$ \\
\hline White blood cell & $20,500 / \mathrm{mm}^{3}$ & Hemoglobin A1c & $7.4 \%$ \\
\hline Band neutrophil & $13 \%$ & Serum osmolality & $371 \mathrm{mOsm} / \mathrm{kg}$ \\
\hline Segmented neutrophil & $65 \%$ & & \\
\hline Red blood cell & $495 \times 10^{4} / \mathrm{mm}^{3}$ & Urinalysis & \\
\hline Hemoglobin & $15.2 \mathrm{~g} / 100 \mathrm{ml}$ & Protein & $( \pm)$ \\
\hline Hematocrit & $50.7 \%$ & Glucose & $(4+)$ \\
\hline Platelets & $33.0 \times 10^{4} / \mathrm{mm}^{3}$ & Ketone body & $(2+)$ \\
\hline \multicolumn{2}{|c|}{ Erythrocyte sedimentation rate } & Occult blood & $(3+)$ \\
\hline \multicolumn{4}{|c|}{$22 \mathrm{~mm} / \mathrm{h}$} \\
\hline & & Serology & \\
\hline \multicolumn{2}{|l|}{ Blood chemistry } & C-reactive protein & $10.3 \mathrm{mg} / 100 \mathrm{ml}$ \\
\hline Total protein & $6.6 \mathrm{~g} / 100 \mathrm{ml}$ & & \\
\hline Albumin & $4.24 \mathrm{~g} / 100 \mathrm{ml}$ & Arterial blood gas & \\
\hline Blood urea nitrogen & $65.8 \mathrm{mg} / 100 \mathrm{ml}$ & $\mathrm{pH}$ & 6.996 \\
\hline Creatinine & $2.1 \mathrm{mg} / 100 \mathrm{ml}$ & $\mathrm{PaCO}_{2}$ & $12.6 \mathrm{mmHg}$ \\
\hline Blood uric acid & $11.9 \mathrm{mg} / 100 \mathrm{ml}$ & $\mathrm{PaO}_{2}$ & $135 \mathrm{mmHg}$ \\
\hline Total bilirubin & $0.4 \mathrm{mg} / 100 \mathrm{ml}$ & $\mathrm{HCO}_{3}^{-}$ & $3.1 \mathrm{mmol} / \mathrm{l}$ \\
\hline Aspartate aminotransferase & $45 \mathrm{KU}$ & $\mathrm{BE}$ & $-28.4 \mathrm{mmol} / \mathrm{l}$ \\
\hline Alanine aminotransferase & $49 \mathrm{KU}$ & & \\
\hline Lactate dehydrogenase & $388 \mathrm{WU}$ & Others & \\
\hline Alkaline phosphatase & $14.3 \mathrm{KA}$ & Urine C-peptide & $6.1 \mu \mathrm{g} / \mathrm{day}$ \\
\hline \multirow[t]{2}{*}{$\gamma$-glutamyltransferase } & $42 \mathrm{IU} / l$ & & \\
\hline & & Coagulation test & \\
\hline Sodium & $122 \mathrm{mEq} / \mathrm{l}$ & Prothrombin time & $36 \%$ \\
\hline Potassium & $6.9 \mathrm{mEq} / \mathrm{l}$ & Activated partial pr & bin time \\
\hline Chloride & $81 \mathrm{mEq} / \mathrm{l}$ & & $40 \mathrm{sec}$ \\
\hline Calcium & $4.8 \mathrm{mEq} / \mathrm{l}$ & Fibrinogen & $558 \mathrm{mg} / 100 \mathrm{ml}$ \\
\hline \multirow[t]{2}{*}{ Inorganic phosphate } & $10.1 \mathrm{mg} / 100 \mathrm{ml}$ & Serum fibrin degra & roducts \\
\hline & & & $30.1 \mu \mathrm{g} / \mathrm{ml}$ \\
\hline
\end{tabular}

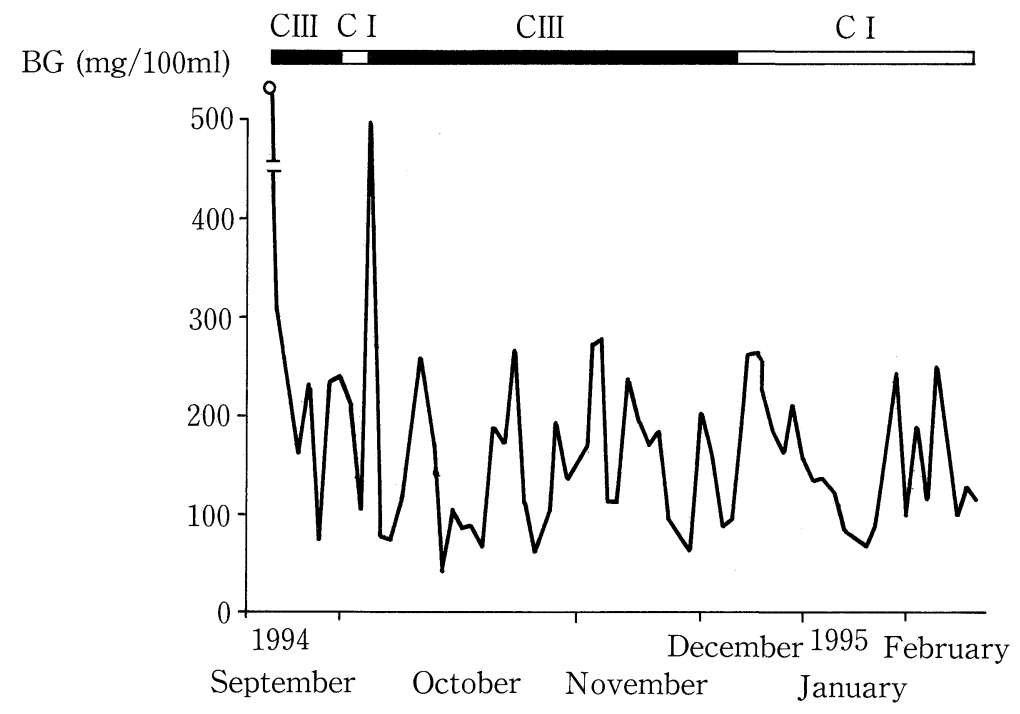

Figure 1. The change of blood glucose. BG: blood glucose, CIII: continuous intravenous insulin infusion therapy, CI: conventional insulin therapy, $\bigcirc$ : BG level was $1,163 \mathrm{mg} / 100 \mathrm{ml}$ on admission. 


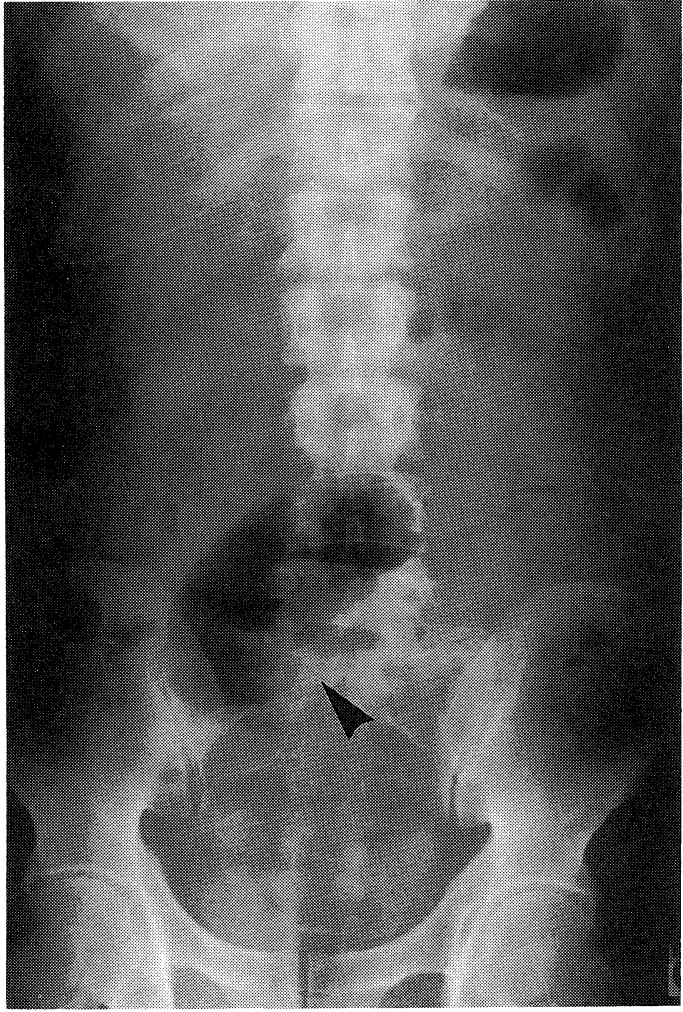

Figure 2. Abdominal plain X-ray film on admission showed the enlargement of sigmoid colon $(\varangle)$.

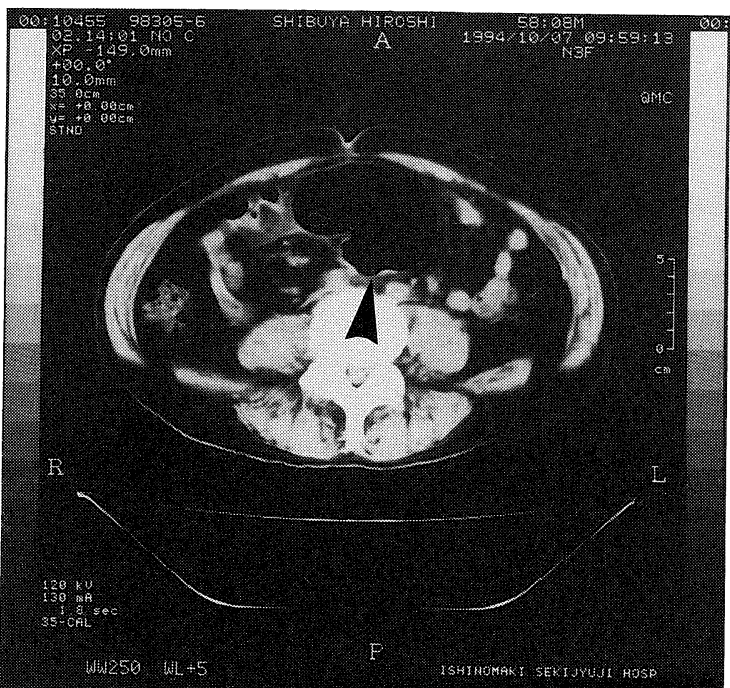

Figure 3. Pelvic CT on October 7, 1994. Enlarged colon was noted $(\varangle)$.

4). A barium enema of small bowel was not performed. Colonoscopy, performed on November 21, 1994, showed the sigmoid colon had a cobblestone appearance, with a longitudinal ulcer and severe stenosis, which was impossible to observe

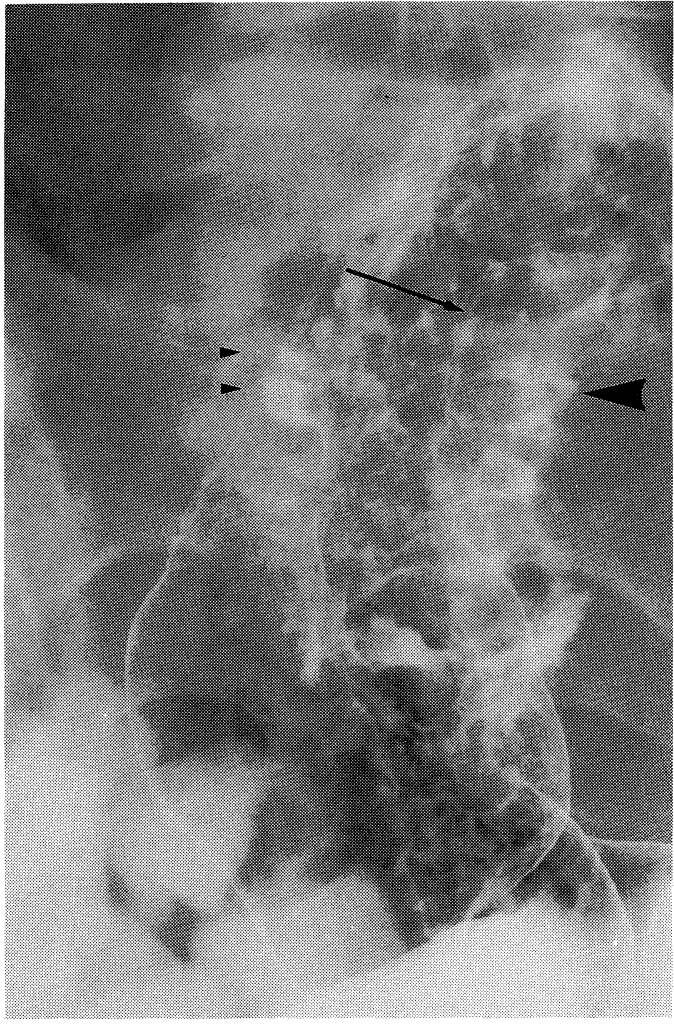

Figure 4. The barium enema of the colon on November 2, 1994 showed serrated mucosa ( $<)$, cobblestoned appearance $(\measuredangle)$ and longitudinal ulcer $(\leftarrow$ ) of the sigmoid colon.

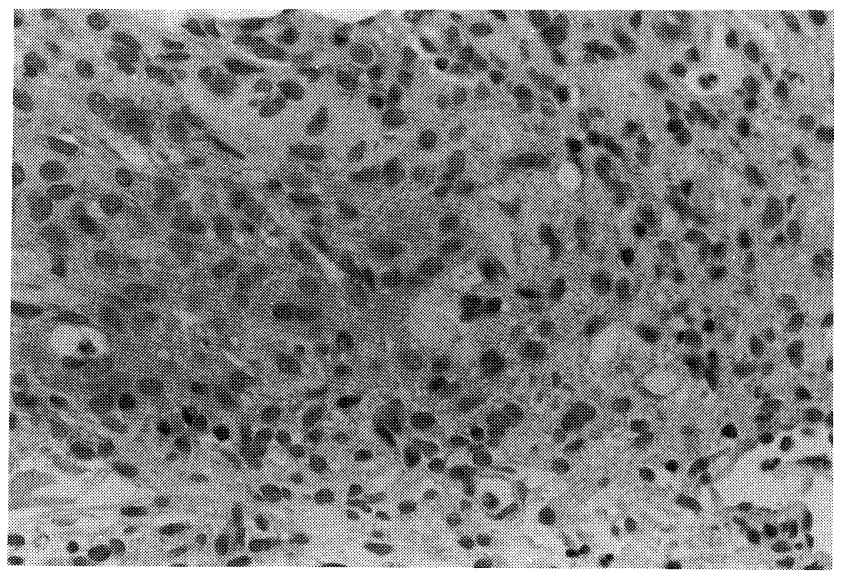

Figure 5. The colonoscopic biopsy specimen obtained from the ulcer bed of the sigmoid colon. Non-caseating granuloma was recognized (HE stain, $\times 200$ ).

further. Colonoscopic biopsy specimens from the sigmoid colon revealed non-caseating granuloma (Fig. 5). Immunological examination revealed no other abnormalities, except for positive results of IgG and IgM aCLs and histocompatibility 
Table 2. Immunological Examination on October 18,1994

\begin{tabular}{lr}
\hline CH50 & $40.4 \mathrm{CH} 50 \mathrm{U} / \mathrm{ml}$ \\
ANA & $(-)$ \\
anti DNA antibody & $(-0 \mathrm{IU} / \mathrm{ml}$ \\
anti Sm antibody & $(-)$ \\
anti RNP antibody & $(-)$ \\
RA test & $(-)$ \\
Lupus anticoagulant & \\
IgG anticardiolipin antibody* & 3.9 \\
IgM anticardiolipin antibody* & 6.6 \\
& \\
anti Insulin antibody & $5.7 \%$ \\
anti islet antibody & $(-)$ \\
HLA $\cdot$ DR4 & $(+)$ \\
\hline
\end{tabular}

ANA: anti nuclear antibody, HLA: histocompatibility antigen, RA: rheumatoid arthritis, RNP: ribonucleo-protein. *: assay was done by the means of enzyme linked immunosorbent assay and it's normal range was under 1.0, (-): negative result, $(+)$ : positive result.

antigen (HLA) DR4 (Table 2). Based on the results of these examinations, the patient was diagnosed as diabetes mellitus (DM) with aCL-associated CD. Corticosteroid hormone treatment $(900 \mathrm{mg} /$ day intravenous infusion of hydrocortisone) was started on October 5 . The abnormalities in the coagulate system returned to normal 5 days after the start of treatment. Salazosulfapyridine treatment was started on November 17, and his clinical course markedly improved and aCLs eventually changed to negative as shown in Fig. 6. Colonoscopy on January 23, 1995 showed almost normal mucosa in the lower sigmoid colon, although severe stenosis was still present. The patient was discharged on February 29, 1995.

\section{Discussion}

$\mathrm{CD}$ is very difficult to distinguish from ischemic colitis (15). In the present case, the patient had a high fever of unexplained origin with no bowel symptoms or extracolonic manifestations such as arthritis or liver disease antedating or overshadowing the bowel involvement (16), and a cobblestone appearance and a longitudinal ulcer were revealed by a barium enema and colonoscopy (16). Colonic mucosal biopsy also revealed granuloma (16). Based on these clinical and histological findings, we thought it may be reasonable to diagnose this case as CD.

Vianna et al were the first to report a case of $\mathrm{CD}$ associated with aCL (3). Later, Chamouard et al reported that the aCL was present in about $20 \%$ of CD cases (2). The presence of aCL is observed in the active or quiescent phase of $\mathrm{CD}(8)$, and the presence of aCL is not related to episodes of thrombotic events
(2). Although the inflammation process in $\mathrm{CD}$ can sometimes explain the increased thrombotic risk, it is thought that the presence of aCL may accelerate the thrombotic mechanism, because $\mathrm{aCL}$ is considered to reveal potentially thrombogenic cellular alterations (2). In the present case, the abnormalities in the coagulate system were decreased prothrombin time and increased serum fibrinogen, which is the most frequently reported hemostasis abnormality and an important risk factor for arterial thrombosis (11), and increased serum fibrin degradation products. Thromboembolic episodes were not observed. Although it has been reported that the presence of aCL may be associated with genetic factors, such as HLA DR7 or DRW53 (2), in the present case, only DR4 was recognized by the examination of HLA. On the other hand, Matake et al reported that DR4 is generally recognized in Japanese CD patients (17). It was also reported that DR4 and DR53 are more frequent in aCL-positive CD patients (18). The present case presented two interesting problems. The first is that DM and CD occurred at the same time. Although it is uncertain whether one was an accidental complication of the other, it may be speculated that the possibility of outcome of these two diseases at the same time, because the pathogenesis of one of these two diseases has been recognized as an abnormal immunological mechanism ( 1 , 2) and these two diseases have the same hireditary factor, such as DR4 $(18,19)$. To the best of our knowledge, there are no case reports of both DM and CD occurring concurrently. The second problem is the change of aCL in the clinical course. It was reported that treatment with corticosteroid hormones seems to reduce the level of aCL (2). In the present case, aCL was positive in the active phase but following the clinical improvement by treatment with corticosteroid hormones and salazosulfapyridine, aCL became negative (Fig. 6). The abnormalities in the coagulate system in our case returned to normal following treatment with corticosteroid hormones. It was uncertain whether the abnormalities in the coagulate system in our case were due to $\mathrm{DM}$ or $\mathrm{CD}$, as abnormalities in the coagulate system in DM have been reported (20). It has been demonstrating that $\mathrm{CD}$ granuloma often have a vascular origin, that intestinal microvessels could participate in the initiation of such lesions, and that microthrombotic episodes may play a role in the development of intestinal ulcerations (12). It was thus speculated that aCL, in our case, may play a role in the mechanism of vascular injury in CD.

\section{References}

1) Glickman RM. Inflammatory Bowel Disease. in: Harrison's Principles of Internal Medicine (13th ed), Isselbacher KJ, Braunwald E, Wilson JD, Martin JB, Fauci AS, Kasper DL, Eds. McGraw-Hill Inc., New York, 1994, p. 1404.

2) Chamouard $P$, Grunebaum $L$, Wiesel ML, et al. Prevalence and significance of anti-cardiolipin antibodies in Crohn's disease. Dig Dis Sci 39: 1501, 1994 (see comments).

3) Vianna JL, D'Cruz DP, Khamashta MA, Asherson RA, Hughes GRV. Anticardiolipin antibodies in a patient with Crohn's disease and thrombosis. Clin Exp Rheumatol 10: 165, 1992.

4) Talbot RW, Heppell J, Dozois RR, Beart RW Jr. Vascular complications of inflammatory bowel disease. Mayo Clin Proc 61: 140, 1986. 

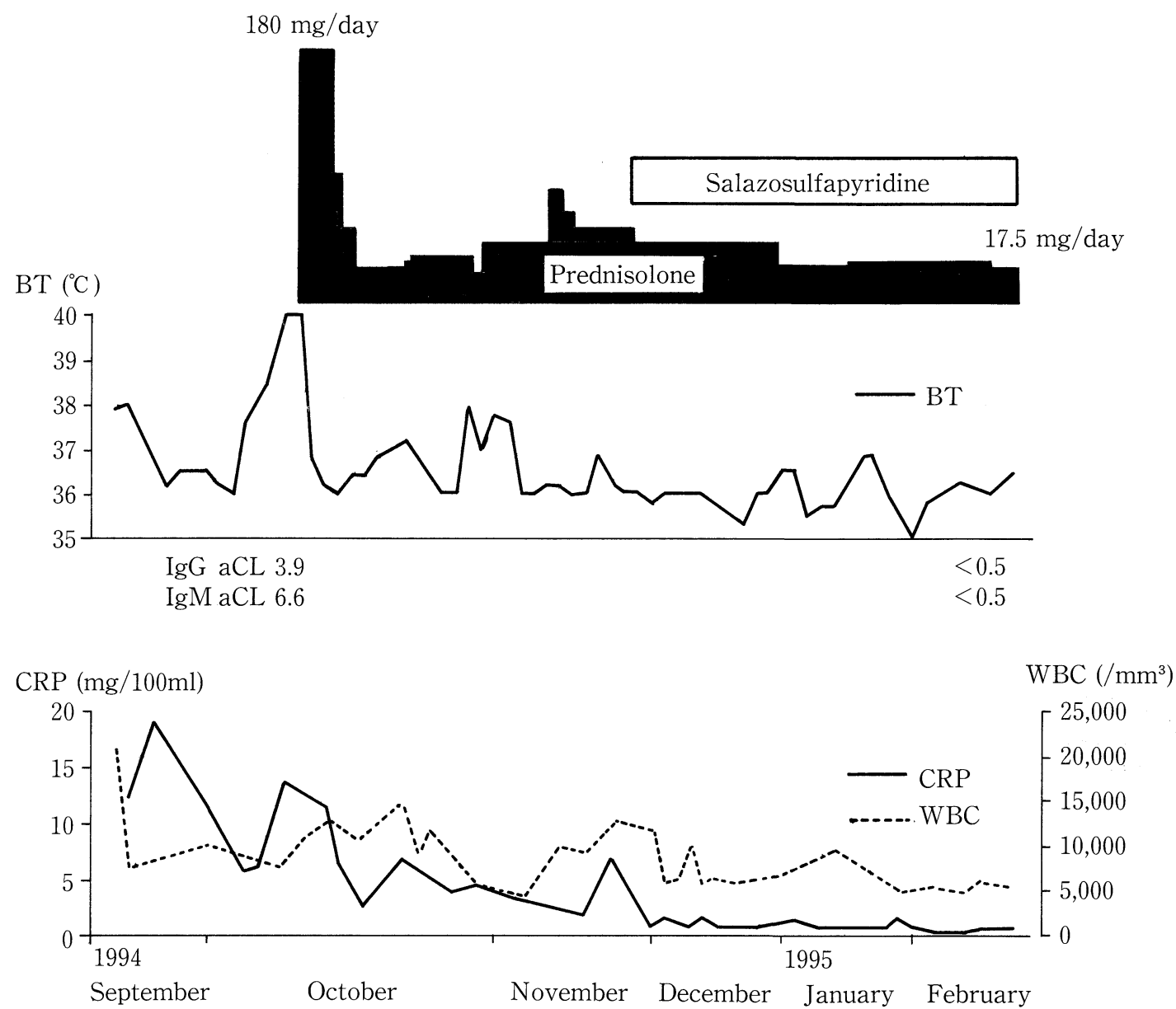

Figure 6. Clinical course. The improvement of body temperature, C-reactive protein and white blood cell were followed by the treatment. In this table, the dose of corticosteroid hormon was revealed as converted dosage of prednisolone, which maximum dose was $180 \mathrm{mg} / \mathrm{day}$ and maintenance dose $17.5 \mathrm{mg} /$ day. aCL: anticardiolipin antibody, BT: body temperature, CRP: C-reactive protein, WBC: white blood cell.

5) Lam A, Borda IT, Inwood MJ, Thomson S. Coagulation studies in ulcerative colitis and Crohn's disease. Gastroenterology 68: 245, 1975.

6) Leardi S, Amoroso A, Afeltra A, et al. Blood coagulation alterations and thromboembolism in Crohn's disease. Ital J Surg Sci 13: 197, 1983.

7) Lake AM, Stauffer JQ, Stuart MJ. Hemostatic alterations in inflammatory bowel disease. Response to therapy. Am J Dig Dis 23: 897, 1978.

8) Conlan MG, Haire WD, Burnett DA. Prothrombotic abnormalities in inflammatory bowel disease. Dig Dis Sci 34: 1089, 1989.

9) Halliday CEW, Farthing MJG. Arterial thrombosis in Crohn's disease. Med J Aust 149: 559, 1988.

10) Talstad I, Rootwelt K, Gjone E. Thrombocytosis in ulcerative colitis and Crohn's disease. Scand J Gastroenterol 8: 135, 1970.

11) Vecchi M, Cattaneo M, de Franchis R, Mannucci PM. Risk of thromboembolic complications in patients with inflammatory bowel disease. Study of hemostasis measurements. Int J Clin Lab Res 21: 165, 1991.

12) Wakefield AJ, Sankey EA, Dhillon AP, et al. Granulomatous vasculitis in Crohn's disease. Gastroenterology 100: 1279, 1991 (published erratum appears in Gastroenterology 101: 595, 1991).

13) Harris EN, Gharavi AE, Boey ML, et al. Anticardiolipin antibodies: detection by radioimmunoassay and association with thrombosis in systemic lupus erythematosus. Lancet ii: 1211, 1983.

14) Ohta T, Waga S, Handa H, Saito I, Suzuki J, Takeuchi K. New grading of level of disordered consciousness (author's transl). No Shinkei Geka 2: 623, 1974 (Abstract in English).

15) Glickman RM. Inflammatory Bowel Disease. in: Harrison's Principles of Internal Medicine (13th ed), Isselbacher KJ, Braunwald E, Wilson JD, Martin JB, Fauci AS, Kasper DL, Eds. McGraw-Hill Inc., New York, 1994, p.1411.

16) Glickman RM. Inflammatory Bowel Disease. in: Harrison's Principles of Internal Medicine (13th ed), Isselbacher KJ, Braunwald E, Wilson JD, Martin JB, Fauci AS, Kasper DL, Eds. McGraw-Hill Inc., New York, 1994, p. 1408 .

17) Matake $H$, Naito $S$, Ogawara S, et al. HLA study in 108 Japanese patients with Crohn's disease. Nippon Shokakibyo Gakkai Zasshi 86: 1448, 1989 (Abstract in English).

18) McNeil HP, Gavaghan TP, Krilis SA, Geczy AF, Chesterman CN. HLADR antigens and anticardiolipin antibodies. Clin Exp Rheumatol 8: 425, 1990 (letter).

19) Foster DW. Diabetes Mellitus. in: Harrison's Principles of Internal Medicine (13th ed), Isselbacher KJ, Braunwald E, Wilson JD, Martin JB, Fauci AS, Kasper DL, Eds. McGraw-Hill Inc., New York, 1994, p.1981.

20) Kanzaki T, Saitou Y. Cell biology of diabetic macroangiopathy. Pharma Medica 10: 45, 1992 (in Japanese). 